\title{
ANALISIS TINGKAT KEPUASAN KONSUMEN TERHADAP BAURAN PEMASARAN BEL MART BOGOR
}

\section{THE LEVEL OF CUSTOMERS STATISFACTION ON MARKETING MIX OF BEL MART BOGOR}

\author{
Tri Megasari $\mathrm{A}^{1}$, Ita Novita $^{1 \mathrm{a}}$, Arti Yoesdiarti ${ }^{1}$ \\ ${ }^{1}$ Jurusan Agribisnis, Fakultas Pertanian Universitas Djuanda Bogor \\ Jalan Tol Ciawi No. 1 Kotak Pos 35 Bogor 16720 \\ a'Korespondensi: Ita Novita. Telp: 0817400272; E-mail: novitazulfan@yahoo.co.id
}

\begin{abstract}
This study was aimed to describe the general customer characteristics of Bel Mart Bogor,the importance and performance of marketing mix that implemented by Bel Mart Bogor with importance-performance analysis(IPA), and the level of customer satisfaction with Customer Satisfaction Index (CSI) . The sampling technique used was convenience sampling with a sample size of 50 people. Based on this research, customers who shop at Bel Mart Bogor is dominated by women who had been married and work as a housewife. Based on the distribution of age, customersare in the range of 26-35 years of age. The level of customers education are predominantly undergraduate. Total food consumption expenditure per month ranged between $\geq \operatorname{Rp~4.000.000,00~-~Rp~5.000.000,00~and~the~number~of~visits~are~} 3$ to 4 times a month.IPA results indicate that the marketing mix variables that should be a priority in the implementation of performance improvement are: store location, parking area,store design and layout, and the store convenience. CSI value of the marketing mix of Bel Mart Bogor is 76,83 percent, which means customers have been satisfied with the performance of the marketing mix of Bel Mart Bogor .
\end{abstract}

Key words : marketing mix, importance-performance analysis, customer satisfaction.

\section{ABSTRAK}

Penelitian ini bertujuan untuk menganalisis karakteristik umum konsumen Bel Mart Bogor, tingkat kepentingan dan kinerja bauran pemasaran BelMart Bogor menggunakan Importance Performance Analysis(IPA), serta tingkat kepuasan konsumen Bel Mart Bogor menggunakan Customer Satisfaction Index (CSI). Teknik pengambilan sampel yang digunakan adalah convenience sampling dengan jumlah sampel sebanyak 50 orang. Berdasarkan hasil penelitian, konsumen yang berbelanja di Bel Mart Bogor didominasi oleh perempuan yang telah menikah dengan pekerjaan sebagai Ibu rumah tangga. Berdasarkan sebaran usia, konsumen Bel Mart Bogor berada pada kisaran usia 26-35 tahun. Tingkat pendidikan konsumen sebagian besar adalah Sarjana. Jumlah pengeluaran konsumsi bahan pangan per bulan berkisar $\geq$ Rp. 4.000.000,00 - Rp. 5.000.000,00. Jumlah kunjungan berbelanja di Bel Mart Bogor sebanyak 3-4 kali dalam sebulan. Hasil analisis IPA menunjukkan bahwa variabel bauran pemasaran yang harus dijadikan prioritas dalam peningkatan kinerja pelaksanaannya adalah: Elokasi gerai, sarana parkir, desain dan layout gerai, serta kenyamanan gerai. Nilai CSI terhadap bauran pemasaran Bel Mart Bogor adalah sebesar 76,83 persen. Nilai tersebut berada pada selang 66,7 - 83,3 persen artinya konsumen telah merasa puas terhadap kinerja bauran pemasaran Bel Mart Bogor.

Kata Kunci : bauran pemasaran, importance- performance analysis, kepuasan konsumen. 


\section{PENDAHULUAN}

Salah satu kegiatan hilir yang berperan penting dalam agribisnis adalah pemasaran, karena pemasaran merupakan pelaksanaan kegiatan yang mengarahkan aliran produk dari produsen ke konsumen dalam rangka memberikan kepuasan kepada konsumen dan mewujudkan tujuan perusahaan (Tjiptono dan Chandra, 2012).

Setiap perusahaan agribisnis harus selalu berusaha memberikan kepuasan kepada konsumen, karena pada dasarnya tujuan dari suatu bisnis adalah untuk menciptakan kepuasan para konsumen. Kepuasan konsumen merupakan konsep sentral dalam semua kegiatan perusahaan. Peningkatan kepuasan konsumen berpotensi memberikan pertumbuhan penjualan jangka panjang dan jangka pendek, serta pangsa pasar sebagai hasil dari pembelian ulang. Sebaliknya, ketidakpuasan konsumen akan memunculkan sejumlah resiko bagi sebuah perusahaan seperti pemboikotan atau protes dari lembaga konsumen, keluhan pelanggan, intervensi pemerintah, dan reaksi pesaing (Tjiptono dan Chandra, 2012).

PT. Sierad Produce Tbk (SIPD) merupakan salah satu perusahaan agribisnis dalam subsektor peternakan ayam broiler yang telah terintegrasi. Salah satu kegiatan hilir yang dilakukan oleh perusahaan tersebut adalah membangun jaringan ritel modern berbentuk convenience store bernama Bel Mart yang menjual berbagai variasi produk daging ayam baik segar maupun olahan dengan jaminan keamanan dan kualitas produknya. Pembangunan Bel Mart menjadi salah satu langkah strategis PT Sierad Produce Tbk dalam meningkatkan pangsa pasar. Berdasarkan Livestock Review (2012), pangsa pasar PT Sierad Produce Tbk masih jauh dibawah pangsa pasar para perusahaan pesaingnya.

Tahun 2012 PT Sierad Produce Tbk secara keseluruhan baru berhasil menguasai 7 persen pangsa pasar dalam industri peternakan ayam broiler. Oleh karena itu PT Sierad Produce Tbk harus terus meningkatkan kinerja strategi pemasarannya untuk dapat meningkatkan pangsa pasar.

BelMart sebagai salah satu ritel modern dengan konsep specialty storey menawarkan berbagai jenis produk daging ayam baik segar maupun olahan harus dapat memberikan keunggulan tersendiri agar tetap kompetitif dan menarik minat beli konsumen dengan mengaplikasikan berbagai alat pemasarannya (bauran pemasaran). Bauran pemasaran tersebut harus dapat memberikan kepuasan kepada konsumen, karena kepuasan konsumen merupakan indikator penting dalam mengukur kinerja perusahaan, dan kepuasan konsumen dapat digunakan sebagai pendorong bagi peningkatan pangsa pasar dan profitabilitas suatu perusahaan (Assauri, 2011).

Berdasarkan uraian yang telah dikemukakan maka pertanyaan penting yang timbul adalah : Bagaimanakah karakteristik umum konsumen Bel Mart Bogor ? Bagaimanakah tingkat kepentingan dan kinerja bauran pemasaran Bel Mart Bogor ? Bagaimanakah tingkat kepuasan terhadap bauran pemasaran $\mathrm{Bel}$ Mart Bogor?

Penelitian ini bertujuan: mengidentifikasi karakteristik umum konsumen, menganalisis tingkat kepentingan atribut bauran pemasaran, dan menganalisis tingkat kepuasan konsumen terhadap kinerja bauran pemasaran $\mathrm{Bel}$ Mart Bogor.

\section{BAHAN DAN METODE}

\section{Kerangka Pemikiran Teoritis}

Bauran pemasaran merupakan seperangkat alat pemasaran yang digunakan perusahaan untuk terus-menerus mencapai tujuan pemasarannya di pasar sasaran (Kotler, 2009).

Kepuasan konsumen adalah pendorong utama bagi retensi dan loyalitas pelanggan. Selain itu peningkatan kepuasan konsumen sangat dibutuhkan dalam persaingan pasar yang semakin tajam. Tingkat kepuasan konsumen tergantung pada kinerja yang dirasakan 
atau diterima dari produk atau jasa dan pelayanan pendukung serta standar penilaian konsumen untuk mengevaluasi kinerja tersebut (Assauri, 2011).

Pengukuran kepuasan konsumen menjadi kebutuhan dalam perusahaan karena tujuan dari perusahaan adalah untuk memberikan yang terbaik kepada konsumen. Kotler (2004) dalam Tjiptono (2005) selanjutnya mengidentifikasi empat metode untuk mengukur kepuasan konsumen yaitu dengan sistem keluhan dan saran, ghost shopping, lost costumer analysis dan survei kepuasan konsumen.

Pengukuran kepuasan konsumen melalui metode ini dapat dilakukan dengan berbagai cara di antaranya (Sumarwan, 2013): Directed Reported Satisfaction Pengukuran dilakukan menggunakan halhal spesifik yang menanyakan langsung tingkat kepuasan yang dirasakan konsumen, jawaban disajikan dengan menggunakan skala. Derived Satisfaction Setidaknya terdapat dua pertanyaan yang diajukan dalam survei dengan metode ini yaitu tingkat harapan atau ekspektasi konsumen pada variabel-variabel yang relevan dan persepsi konsumen terhadap kinerja aktual produk atau perusahaan bersangkutan.

Dalam metode ini terdapat dua teknik yaitu: Problem Analysis, pada teknik ini, responden diminta mengungkapkan masalah-masalah yang mereka hadapi berkaitan dengan produk atau jasa perusahaan dan saran-saran perbaikan. Importance-Performane Analysis, pada teknik ini, responden diminta untuk menilai tingkat kepentingan dan kinerja berbagai variabel yang relevan.

\section{Lokasi Penelitian dan Pengumpulan Data}

Penelitian ini dilakukan di Bel Mart Convenience Meat Shop yang berlokasi di Jalan Pandu Raya No. 27 Bogor. Pemilihan lokasi dilakukan secara sengaja (purposive) karena BelMart adalah jaringan ritel modern (convenience store) yang dibangun oleh PT. Sierad Produce Tbk Waktu pengumpulan data dimulai dari 1 Agustus 2013 - 1 Oktober 2013.
Metode pengambilan sampel yang digunakan dalam penelitian ini adalah nonprobability sampling. Sampel yang digunakan sebagai responden dalam penelitian ini adalah konsumen BelMart Bogor dengan kriteria: responden adalah konsumen yang pernah membeli dan mengkonsumsi produk daging ayam baik segar maupun olahan di BelMart Bogor minimal 2 kali dalam tiga bulan terakhir, dan berusia $\geq 15$ tahun. Jumlah sampel 50 orang.

Data primer diperoleh melalui wawancara dengan pihak manajemen BelMart Bogor, kuesioner kepada responden, serta pengamatan langsung di lapangan. Data sekunder diperoleh dari studi dokumentasi berupa dokumen resmi yang diterbitkan oleh perusahaan untuk mendapatkan informasi berhubungan dengan manajemen BelMart, data resmi yang diterbitkan oleh Badan Pusat Statistik RI, jurnal ilmiah, buku, dan literatur pendukung lainnya yang relevan dengan penelitian ini.

\section{Metode Analisis}

Analisis deskriptif digunakan untuk menganalisis karakteristik konsumen BelMart Bogor yang meliputi jenis kelamin, usia, domisili, status pernikahan, tingkat pendidikan, pekerjaan, rata-rata pengeluaran untuk konsumsi pangan per bulan, dan frekuensi berbelanja per bulan di BelMart Bogor. Untuk mengukur kepuasan konsumen menggunakan analisis Importance - Performance Analysis (IPA). Konsep IPA merupakan pengukuran tingkat kepentingan variabel dan tingkat kinerja pelaksanaan dari suatu variabel. IPA akan menghasilkan berbagai persepsi konsumen tentang kepentingan dan kinerja dari suatu variabel.

Langkah-langkah yang digunakan dalam IPA adalah (Supranto, 2011): menentukan jumlah skor dari setiap indikator variabel dengan mengalikan seluruh frekuensi data dengan bobotnya. Total penilaian tingkat kepentingan masing-masing atribut diperoleh dengan cara menjumlahkan hasil perkalian skor masing-masing skor dengan jumlah 
responden yang memilih pada skor tersebut. Skala yang digunakan dalam mengukur tingkat kepentingan dan kinerja bauran pemasaran dalam penelitian ini adalah skala ordinal melalui teknik skala likert dengan skala yang seimbang untuk menghindari ketidakpastian responden (central tendency) yaitu kecenderungan responden memilih jawaban tengah atau kategori netral (Simamora, 2004). Penilaian tersebut dapat dilihat pada Tabel 1 dengan skor tertinggi adalah 6 .

Tabel 1. Bobot Skor dari Jawaban Responden

\begin{tabular}{llc}
\hline \multicolumn{1}{c}{ Option Kinerja $(\mathbf{X})$} & \multicolumn{1}{c}{ Option Kepentingan $(\mathbf{Y})$} & Skor Jawaban \\
\hline Sangat Baik & Sangat Penting & 6 \\
Baik & Penting & 5 \\
Cukup Baik & Cukup Penting & 4 \\
Kurang Baik & Kurang Penting & 3 \\
Tidak Baik & Tidak Penting & 2 \\
Sangat Tidak Baik & Sangat Tidak Penting & 1 \\
\hline
\end{tabular}

Skor rata rata tingkat kepentingan $(\ddot{\boldsymbol{Y}})$ dan skor rata-rata tingkat kinerja $(\square)$ diperoleh dengan membagi skor total dengan banyaknya responden, hasilnya berupa

Keterangan:

$$
\square=\frac{\sum X i}{n} \ddot{Y} i=\frac{\sum Y i}{n}
$$

$\boldsymbol{\Sigma} \boldsymbol{X i}=$ Total skor tingkat kinerja variabel ke $-i$ dari seluruh responden

$\sum \mathbf{Y}_{\mathbf{i}}=$ Total Skor tingkat kepentingan variable ke - I dari seluruh responden

$\square \mathbf{i}=$ Skor rata-rata tingkat kinerja variable ke-i

$\boldsymbol{y} \boldsymbol{i}=$ Skor rata-rata tingkat kepentingan variable $\mathrm{i}$

$\boldsymbol{n}=$ Jumlah responden

Untuk menganalisis skor rata-rata tingkat kepentingan dan skor rata-rata tingkat kinerja pada IPA Matrix digunakan diagram matriks yang terdiri atas empat kuadran yang menggambarkan tingkat kepentingan dan kinerja tiap variabel. IPA Matrix (Gambar 1) merupakan suatu bangun yang dibagi menjadi empat bagian yang dibatasi oleh dua buah garis yang berpotongan tegak lurus pada titik $(\mathrm{A}, \mathrm{B})$, dengan $\mathrm{A}$ adalah skor rata-rata tingkat kinerja dari seluruh variable, dan B adalah skor rata-rata tingkat kepentingan dari seluruh variabel. Nilai A dan B diukur dengan menggunakan rumus:

$$
A=\frac{\sum}{k} \quad \text { dan } \quad B=\frac{\sum \ddot{Y}}{k}
$$

Keterangan:

$\boldsymbol{A}=$ Batas sumbu X (tingkat kinerja)

$\sum \square \quad=$ Jumlah skor rata-rata tingkat kinerja

$\sum \ddot{\boldsymbol{Y}} \quad=$ Jumlah skor rata tingkat kinerja

$\boldsymbol{B} \quad=$ Batas sumbu Y (tingkat kepentingan)

$\boldsymbol{k}=$ Jumlah indikator dimensi bauran pemasaran (dalam penelitian ini $\mathrm{k}$ =19)

Customer Satisfaction Index (CSI) atau Indeks Kepuasan Konsumen merupakan salah satu alat ukur yang dapat mendukung analisis IPA, Indeks kepuasan pelanggan juga alat ukur yang mampu merepresentasikan kepuasaan konsumen secara menyeluruh dengan melihat tingkat kepentingan dari atribut produk. Tahapan pengukuran CSI terdiri atas empat tahapan perhitungan, yaitu Startford (2008) dalam Harnasari (2009):

(1) menjumlahkan semua skor tingkat kepentingan rata-rata hasil perhitungan IPA dari tiap variabel,

(2) menghitung bobot skor tingkat kepentingan/Weighted Importance Score dengan membagi skor tingkat kepentingan rata-rata per variabel dengan tingkat kepentingan rata-rata total: 
Keterangan:

$$
W I S=\frac{\ddot{Y} i}{\sum \ddot{Y}}
$$

WIS = Weighted Importance Score

$\ddot{Y} i=$ Rata-rata tingkat kepentingan variabel ke- $i$

$\sum \ddot{Y}=$ Jumlah Tingkat Kepentingan dari seluruh variabel.

(3) mengalikan skor tingkat kinerja ratarata variabel ke- $i$ dari perhitungan IPA dengan WIS ke- $i$ hasilnya adalah bobot skor tingkat kepuasan:

$$
W S S=\ddot{Y} i x W I S i
$$

Keterangan:

$$
\begin{aligned}
\boldsymbol{W I S i}= & \text { Weighted Importance Score } \\
& \text { variabel ke- } i \\
\boldsymbol{W S S}= & \text { Weighted Satisfaction Score } \\
\boldsymbol{W A T}= & \text { Weight Avarage Total dengan } \\
& \text { menjumlah semua WSS }
\end{aligned}
$$

Menghitung indeks kepuasan konsumen dengan membagi WAT dengan skor tertinggi yaitu enam (6) kemudian dikalikan dengan 100 persen:

Keterangan:

$$
C S I=\frac{W A T}{m} x 100 \%
$$

\section{CSI = Customer Satisfaction Index (Indeks Kepuasan Konsumen) \\ m = Skor tertinggi}

Indeks kepuasan konsumen menggunakan rentang skala untuk menunjukkan tingkat kepuasan konsumen terhadap produk. Rentang skala kepuasan konsumen berkisar antara $0-100$ persen. Rumus rentang skala yang digunakan berdasarkan Simamora (2004) adalah sebagai berikut :
Keterangan:

$$
R S=\frac{\mathbf{m}-\mathbf{l}}{\mathbf{b}}
$$

$\boldsymbol{R} \boldsymbol{S}=$ rentang skala

m = skor tertinggi

l = skor terendah

b = jumlah skala yang dibuat

Pada penelitian ini rentang skala yang digunakan adalah:

$$
R S=\frac{100 \%-0 \%}{6}=16.7 \%
$$

Berdasarkan rentang skala diatas maka kriteria kepuasan yang digunakan adalah: $0 \%<\mathrm{CSI} \leq 16,7 \%=$ sangat tidak puas, $16,7 \%<\mathrm{CSI} \leq 33,3 \%=$ tidak puas, $33,3 \%<\mathrm{CSI} \leq 50 \%=$ kurang puas, $50 \%$ $<\mathrm{CSI} \leq 66,7 \%=$ cukup puas, $66,7 \%<\mathrm{CSI}$ $\leq 83,3 \%=$ puas, $83,3 \%<\mathrm{CSI} \leq 100 \%=$ sangat puas.

\section{HASIL DAN PEMBAHASAN}

\section{Analisis Tingkat Kepentingan dan Kinerja (Importance Performance Analysis) Konsumen Bel Mart Bogor.}

Berdasarkan data pada Tabel 1, skor rata-rata dari setiap variabel selanjutnya dapat dianalisis dalam diagram kartesius atau IPA Matrix dengan menggunakan nilai rerata dari seluruh variabel sebagai garis potongnya yang akan membentuk empat kuadran yaitu kuadran I (kuadran prioritas utama), kuadran II (kuadran prioritas prestasi), kuadran III (kuadran prioritas rendah), kuadran IV (kuadran pelaksanaan yang berlebihan) seperti terlihat pada Gambar 1 . 


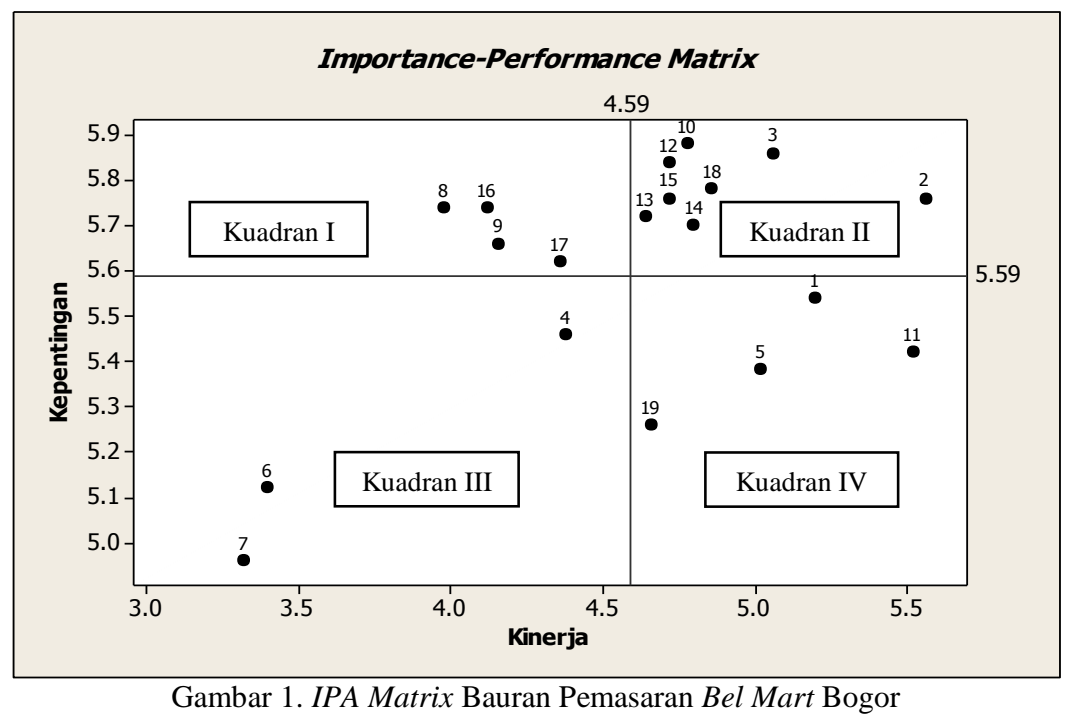

\section{Analisis Customer Satisfaction Index (CSI) Konsumen Bel Mart Bogor}

Tingkat kepuasan konsumen secara keseluruhan dapat diukur menggunakan
CSI dengan mempertimbangkan tingkat kepentingan dari tiap variabel bauran pemasaran yang diukur. Hasil perhitungan CSI adalah seperti terlihat pada Tabel 2.

Tabel 2. Penilaian Responden Terhadap Tingkat Kepentingan dan Tingkat Kinerja Bauran Pemasaran Bel Mart Bogor

\begin{tabular}{clcccc}
\hline No & Variabel & $\sum \mathrm{Y}$ & $\sum \mathrm{X}$ & $\ddot{\mathrm{Y}}$ & $\ddot{\mathrm{X}}$ \\
\hline $\mathbf{1}$ & Produk & & & & \\
$\mathbf{2}$ & Variasi produk daging & 277 & 260 & 5.54 & 5.20 \\
$\mathbf{3}$ & Keterangan halal & 288 & 278 & 5.76 & 5.56 \\
& Hargas produk & 293 & 253 & 5.86 & 5.06 \\
$\mathbf{4}$ & Kesesuaian harga & & & & \\
$\mathbf{5}$ & Potongan harga & 273 & 219 & 5.46 & 4.38 \\
& Promosi & 269 & 251 & 5.38 & 5.02 \\
$\mathbf{6}$ & Iklan media & & & & \\
$\mathbf{7}$ & Sales promotion & 256 & 170 & 5.12 & 3.40 \\
& Tempat & 248 & 166 & 4.96 & 3.32 \\
$\mathbf{8}$ & Lokasi strategis & & & & \\
$\mathbf{9}$ & Sarana parkir & 287 & 199 & 5.74 & 3.98 \\
$\mathbf{1 0}$ & Keramahan dan kesopanan pramuniaga & 283 & 208 & 5.66 & 4.16 \\
$\mathbf{1 1}$ & Seragam pramuniaga & 294 & 239 & 5.88 & 4.78 \\
$\mathbf{1 2}$ & Perhatian pramuniaga & 271 & 276 & 5.42 & 5.52 \\
& Proses & 292 & 236 & 5.84 & 4.72 \\
$\mathbf{1 3}$ & Kecepatan transaksi & & & & \\
$\mathbf{1 4}$ & Alternatif pembayaran & 286 & 232 & 5.72 & 4.64 \\
$\mathbf{1 5}$ & Tanggapan atas keluhan & 285 & 240 & 5.70 & 4.80 \\
& Bukti Fisik & 288 & 236 & 5.76 & 4.72 \\
$\mathbf{1 6}$ & Desain dan layout gerai & & & & \\
$\mathbf{1 7}$ & Kenyamanan gerai & 287 & 206 & 5.74 & 4.12 \\
$\mathbf{1 8}$ & Kebersihan gerai & 281 & 218 & 5.62 & 4.36 \\
$\mathbf{1 9}$ & Pencahayaan gerai & 289 & 243 & 5.78 & 4.86 \\
& Total & 233 & 5.26 & 4.66 \\
& Rata-rata & & & 106.2 & 87.26 \\
\hline & 263 & & & &
\end{tabular}


Berdasarkan hasil penelitian yang dilakukan terhadap konsumen Bel Mart Bogor, diperoleh nilai CSI sebesar 76,83 persen. Nilai CSI tersebut berada pada selang 66,6 - 83,3 persen, yang memiliki arti bahwa konsumenBel Mart Bogor telah merasa puas terhadap kinerja bauran pemasaran Bel Mart Bogor. Oleh karena itu, pihak manajemen Bel Mart Bogor hendaknya mampu mempertahankan kinerja bauran pemasaran yang terdapat pada Kuadran II dan meningkatkan kinerja bauran pemasaran yang berada pada Kuadran I agar dapat selalu memberikan kepuasan kepada konsumen sehingga konsumen pun akan loyal memilih Bel Mart Bogor sebagai tempat untuk berbelanja produk daging ayam segar dan meningkatkan keuntungan bagi perusahaan.

\section{KESIMPULAN DAN IMPLIKASI KEBIJAKAN}

\section{Kesimpulan}

Berdasarkan uraian dan hasil perhitungan Importance-Performance Analysis serta Customer Satisfaction Index terhadap bauran pemasaran Bel Mart Bogor, maka dapat disimpulkan bahwa:

1. Konsumen yang berbelanja di Bel Mart Bogor didominasi oleh perempuan yang telah menikah dengan pekerjaan sebagai Ibu rumah tangga. Berdasarkan sebaran usia, konsumen Bel Mart Bogor berada pada kisaran usia 26-35 tahun. Tingkat pendidikan konsumen

2. Sebagian besar responden adalah sarjana. Pengeluaran konsumsi bahan pangan per bulan berkisar Rp. 4.000.000,00 - Rp.5.000.000,00 dengan jumlah kunjungan 3-4 kali dalam sebulan.

3. Variabel bauran pemasaran yang berada dalam kuadran I atau yang harus dijadikan prioritas dalam peningkatan kinerja pelaksanaannya adalah: lokasi gerai, sarana parkir, desain dan layout gerai, serta kenyamanan gerai. Variabel yang berada dalam kuadran II atau yang harus dipertahankan kinerjanya adalah: keterangan halal, kualitas produk daging ayam, keramahan dan kesopanan pramuniaga, perhatian pramuniaga dalam pelayanan, kecepatan transaksi, fasilitas alternatif pembayaran, tanggapan atas keluhan, dan kebersihan gerai. Variabel yang termasuk kedalam kuadran III atau variabel yang tidak menjadi prioritas untuk ditingkatkan kinerjanya adalah: harga, iklan, dan sales promotion.Variabel yang termasuk kedalam kuadran IV atau variabel yang tidak terlalu dianggap penting oleh konsumen namun pelaksanaannya sudah sangat baik adalah: variasi produk daging ayam, potongan harga, seragam pramuniaga, dan pencahayaan gerai.

4. Nilai CSI terhadap bauran pemasaran Bel Mart Bogor adalah sebesar 76,83 persen. Nilai tersebut berada pada selang 66,6 - 83,8 persen, yang artinya adalah konsumen telah merasa puas terhadap pelaksanaan bauran pemasaran Bel Mart Bogor. Oleh karena itu, Bel Mart Bogor dapat dijadikan sebagai teladan dalam pelaksanaan bauran pemasaran ritel modern.

\section{Implikasi Kebijakan}

1. Meningkatkan kualitas pelaksanaan variabel bauran pemasaran yang berada pada kuadran I, yaitu: lokasi gerai, sarana parkir, desain dan layout gerai, serta kenyamanan gerai.

2. Pihak manajemen dapat mempertimbangkan penambahan lokasi gerai yang dekat dengan daerah perumahan yang karakternya hampir sama dengan karakter perumahan yang ada di daerah jalan Pandu Raya Bogor. Seperti di daerah Sentul dan jalan Pajajaran, jalanYasmin Raya Bogor, yang berdekatan dengan perumahan Taman Yasmin Bogor, dan Bukit Cimanggu. Selainitu, Bel Mart juga perlu memperhatikan pelaksanaan variabel-variabel yang dianggap penting oleh konsumen. 


\section{DAFTAR PUSTAKA}

Assauri S. 2011. Strategic Marketing Sustaining Lifetime Customer value.PT Raja GrafindoPersada. Jakarta.

Direktorat Jenderal Peternakan dan Kesehatan Hewan.2012. Statistik Peternakan dan Kesehatan Hewan. http://ditjennak.deptan.go.id[diundu h: 1Juni 2013].

Harnasari A. 2009. Analisis Proses

Keputusan Pembelian dan Kepuasan Konsumen Cimory Yoghurt Drink di Cimory Shop Bogor [Skripsi]. Departemen Agribisnis Fakultas Ekonomi dan Manajemen Institut Pertanian Bogor. Bogor.

Kotler P. 2000. Manajemen Pemasaran

Edisi Millenium Jilid 1. Penerbit Erlangga. Jakarta.

Kotler P, Keller KL. 2009. Manajemen Pemasaran EdisiTigaBelas Jilid Satu. Penerbit Erlangga. Jakarta.

Lingga VM. 2008. Analisis Kepuasan Konsumen Terhadap Pelaksanaan Bauran Pemasaran (7P) Pada Toserba X Bogor [Skripsi]. Program Sarjana Ekstensi Manajemen Agribisnis Fakultas Pertanian Institut Pertanian Bogor. Bogor.

Nugraha T. 2007. Analisis Respon

Pengunjung Terhadap Kualitas PelayananToko Total Buah Segar Bandung Serta Implikasi Bauran Pemasaran [Skripsi]. Program Sarjana Ekstensi Manajemen Agribisnis Fakultas Pertanian Institut Pertanian Bogor. Bogor.

Pasaribu DA, Sembiring, Beby KF .2013.

$\begin{array}{lcr}\text { Pengaruh } & \text { Strategi } & \text { Bauran } \\ \text { Pemasaran } & \text { Ritel } & \text { Terhadap }\end{array}$

Kepuasan dan Loyalitas Pelanggan Minimarket Mes Mart Syariah [JurnalManajemenPemasaran].Faku ltas Ekonomi Universitas Sumatera Utara. Medan.

Rahman A. 2008. Analisis Kepuasan

Konsumen Produk Susu Ultra Milk [Skripsi]. Program Studi Manajemen Agribisnis Fakultas Pertanian Institut Pertanian Bogor. Bogor.

Rizkiani K. 2011. Analisis Kepuasan

Konsumen Dengan Pendekatan Fuzzy pada Giant Hypermarket Jatiasih Bekasi

Sitepu S. 2008. Analisis Kepuasan

Konsumen Giant Botani Square Bogor [skripsi]. Program Studi Manajemen Agribisnis Fakultas Pertanian Institut Pertanian Bogor. Bogor.

Stanton WJ. 1996. Manajemen

Pemasaran. Penerbit Erlangga. Jakarta.

Sumarwan U, Jauzi A, Mulyana A, Karno BN, Mawardi PK, Nugroho W. 2013. Riset Pemasaran dan Konsumen Seri 1 Cetakan kedua. PT Penerbit IPB Press. Bogor. Tjiptono F. 2005. Pemasaran Jasa, Edisi Pertama, Cetakan Pertama. Bayumedia Publishing. Malang.

Tjiptono F, Chandra. 2012. Kepuasan

Konsumen dan Kepuasan Pelanggan Edisi 2.PT Gramedia Pustaka Utama. Jakarta.

Utomo DA. 2011. Analisis Kepuasan dan Loyalitas Konsumen Prima Fresh Mart Pendekatan Service Quality [Skripsi]. Departemen Agribisnis Fakultas Ekonomi dan Manajemen Institut Pertanian Bogor. Bogor 


\section{Lampiran 1. Indikator Skor Penilaian KonsumenTerhadap Bauran Pemasaran Bel Mart Bogor}

\begin{tabular}{|c|c|c|c|c|c|c|c|}
\hline No & Variabel & 1 & 2 & 3 & 4 & 5 & 6 \\
\hline 1 & $\begin{array}{l}\text { Variasi } \\
\text { Produk }\end{array}$ & $\begin{array}{l}\text { Hanya terdapat } \\
\text { satu varias } \\
\text { iproduk daging } \\
\text { ayam }\end{array}$ & $\begin{array}{l}\text { Terdapat } 2 \text { - } \\
5 \text { variasi } \\
\text { produk } \\
\text { daging ayam }\end{array}$ & $\begin{array}{l}\text { Terdapat 6-9 } \\
\text { variasi produk } \\
\text { daging ayam }\end{array}$ & $\begin{array}{l}\text { Terdapat 10-13 } \\
\text { produk daging } \\
\text { ayam }\end{array}$ & $\begin{array}{l}\text { Terdapat } 13-16 \\
\text { variasi produk } \\
\text { daging ayam }\end{array}$ & $\begin{array}{l}\text { Terdapat lebih dari } 16 \\
\text { variasi produk daginga } \\
\text { yam }\end{array}$ \\
\hline 2 & $\begin{array}{l}\text { Keterangan } \\
\text { Halal }\end{array}$ & $\begin{array}{l}\text { Tidak terdapat } \\
\text { produk daging } \\
\text { ayam dengan } \\
\text { keterangan halal }\end{array}$ & $\begin{array}{l}\text { Terdapat 1- } \\
5 \text { produk } \\
\text { daging ayam } \\
\text { dengan } \\
\text { keterangan } \\
\text { halal }\end{array}$ & $\begin{array}{l}\text { Terdapat } 6-10 \\
\text { produk daging } \\
\text { ayam dengan } \\
\text { keterangan halal }\end{array}$ & $\begin{array}{l}\text { Terdapat } 11-15 \\
\text { produk daging } \\
\text { ayam dengan } \\
\text { keterangan halal }\end{array}$ & $\begin{array}{l}\text { Terdapat } 16-20 \\
\text { produk daging } \\
\text { ayam dengan } \\
\text { keterangan halal }\end{array}$ & $\begin{array}{l}\text { Semua produk daging } \\
\text { ayam dengan } \\
\text { keterangan halal }\end{array}$ \\
\hline 3 & Kualitas & $\begin{array}{l}\text { Kriteria mutu } \\
\text { produk daging } \\
\text { ayam sangat } \\
\text { tidak baik }\end{array}$ & $\begin{array}{l}\text { Kriteria } \\
\text { mutu produk } \\
\text { daging ayam } \\
\text { tidak baik } \\
\end{array}$ & $\begin{array}{l}\text { Kriteria mutu } \\
\text { produk dagin g } \\
\text { ayam kurang } \\
\text { baik }\end{array}$ & $\begin{array}{l}\text { Kriteria mutu } \\
\text { produk daging } \\
\text { ayam cukup baik }\end{array}$ & $\begin{array}{l}\text { Kriteria mutu } \\
\text { produk daging } \\
\text { ayam baik }\end{array}$ & $\begin{array}{l}\text { Kriteria mutu produk } \\
\text { daging ayamsangat } \\
\text { baik }\end{array}$ \\
\hline 4 & $\begin{array}{l}\text { Kesesuaianh } \\
\text { arga yang } \\
\text { ditawarkan }\end{array}$ & $\begin{array}{l}\text { Harga sangat } \\
\text { tidak sesuai } \\
\text { dengan kualitas }\end{array}$ & $\begin{array}{l}\text { Harga tidak } \\
\text { sesuai } \\
\text { dengan } \\
\text { kualitas }\end{array}$ & $\begin{array}{l}\text { Harga kurang } \\
\text { sesuai dengan } \\
\text { kualitas }\end{array}$ & $\begin{array}{l}\text { Harga cukup } \\
\text { sesuai dengan } \\
\text { kualitas }\end{array}$ & $\begin{array}{l}\text { Harga sesuai } \\
\text { dengan kualitas }\end{array}$ & $\begin{array}{l}\text { Harga sangat sesuai } \\
\text { dengan kualitas }\end{array}$ \\
\hline 5 & $\begin{array}{l}\text { Potongan } \\
\text { harga }\end{array}$ & $\begin{array}{l}\text { Frekuensi tidak } \\
\text { pernah, } \\
\text { publikasi tidak } \\
\text { ada, }\end{array}$ & $\begin{array}{l}\text { Frekuensi } \\
\text { sangat } \\
\text { jarang, } \\
\text { publikasi } \\
\text { kurang } \\
\text { gencar } \\
\end{array}$ & $\begin{array}{l}\text { Frekuensi } \\
\text { jarang, } \\
\text { publikasi } \\
\text { kurang gencar }\end{array}$ & $\begin{array}{l}\text { Frekuensi cukup } \\
\text { sering, publikasi } \\
\text { gencar }\end{array}$ & $\begin{array}{l}\text { Frekuensi sering, } \\
\text { publikasi gencar }\end{array}$ & $\begin{array}{l}\text { Frekuensi sangat } \\
\text { sering, publikasi sangat } \\
\text { gencar }\end{array}$ \\
\hline 6 & Iklan & $\begin{array}{l}\text { Media iklan } \\
\text { sangat tidak } \\
\text { efektif dan } \\
\text { frekuensi sangat } \\
\text { jarang }\end{array}$ & $\begin{array}{l}\text { Media iklan } \\
\text { tidak efektif } \\
\text { dan } \\
\text { frekuensi } \\
\text { jarang }\end{array}$ & $\begin{array}{l}\text { Media iklan } \\
\text { kurang efektif } \\
\text { dan frekuensi } \\
\text { jarang }\end{array}$ & $\begin{array}{l}\text { Media iklan } \\
\text { cukup efektif dan } \\
\text { frekuensi cukup } \\
\text { sering }\end{array}$ & $\begin{array}{l}\text { Media iklan } \\
\text { efektif dan } \\
\text { frekuensi sering }\end{array}$ & $\begin{array}{l}\text { Media iklan sangat } \\
\text { efektif dan frekuensi } \\
\text { sangat sering }\end{array}$ \\
\hline 7 & $\begin{array}{l}\text { Sales } \\
\text { Promotion }\end{array}$ & $\begin{array}{l}\text { Sales promotion } \\
\text { sangat tidak } \\
\text { efektif dan } \\
\text { frekuensi sangat } \\
\text { jarang }\end{array}$ & $\begin{array}{l}\text { Sales } \\
\text { promotion } \\
\text { tidak efektif } \\
\text { dan } \\
\text { frekuensi } \\
\text { jarang }\end{array}$ & $\begin{array}{l}\text { Sales } \\
\text { promotion } \\
\text { kurang efektif } \\
\text { dan frekuensi } \\
\text { jarang }\end{array}$ & $\begin{array}{l}\text { Sales promotion } \\
\text { cukup efektif dan } \\
\text { frekuensi cukup } \\
\text { sering }\end{array}$ & $\begin{array}{l}\text { Sales promotion } \\
\text { efektif dan } \\
\text { frekuensi sering }\end{array}$ & $\begin{array}{l}\text { Sales promotion } \\
\text { sangat efektif dan } \\
\text { frekuensi sangat sering }\end{array}$ \\
\hline 8 & Lokasi Gerai & $\begin{array}{l}\text { Sangat sulit } \\
\text { dijangkau }\end{array}$ & $\begin{array}{l}\text { Sulit } \\
\text { dijangkau }\end{array}$ & $\begin{array}{l}\text { Sulit dijangkau } \\
\text { namun terdapat } \\
\text { akses } \\
\text { transportasi } \\
\text { umum }\end{array}$ & $\begin{array}{l}\text { Cukup mudah } \\
\text { dijangkau dan } \\
\text { terdapat akses } \\
\text { transportasi } \\
\text { umum }\end{array}$ & $\begin{array}{l}\text { Mudah } \\
\text { dijangkau } \\
\text { dengan berbagai } \\
\text { akses } \\
\text { transportasi } \\
\text { umum }\end{array}$ & $\begin{array}{l}\text { Sangat mudah } \\
\text { dijangkau dengan } \\
\text { transportasi umum dan } \\
\text { dekat dengan jalan } \\
\text { utama }\end{array}$ \\
\hline 9 & $\begin{array}{l}\text { Sarana } \\
\text { parkir }\end{array}$ & Tidak tersedia & $\begin{array}{l}\text { Tersedia, } \\
\text { sempit }\end{array}$ & $\begin{array}{l}\text { Tersedia, } \\
\text { kurang luas }\end{array}$ & $\begin{array}{l}\text { Tersedia, } \\
\text { cukupluas dan } \\
\text { cukup dekat } \\
\text { dengan toko }\end{array}$ & $\begin{array}{l}\text { Tersedia, luas } \\
\text { dan dekat } \\
\text { dengan toko }\end{array}$ & $\begin{array}{l}\text { Tersedia, sangat luas } \\
\text { dan sangat dekat } \\
\text { dengan toko }\end{array}$ \\
\hline 10 & $\begin{array}{l}\text { Keramahan } \\
\& \text { kesopanan } \\
\text { pramuniaga }\end{array}$ & $\begin{array}{l}\text { Sangat tidak } \\
\text { ramah dan } \\
\text { sangat tidak } \\
\text { sopan }\end{array}$ & $\begin{array}{l}\text { Tidak ramah } \\
\text { dan tidak } \\
\text { sopan }\end{array}$ & $\begin{array}{l}\text { Kurang ramah } \\
\text { dan kurang } \\
\text { sopan }\end{array}$ & $\begin{array}{l}\text { Cukup ramah dan } \\
\text { cukup sopan }\end{array}$ & $\begin{array}{l}\text { Ramah dan } \\
\text { sopan }\end{array}$ & $\begin{array}{l}\text { Sangat ramah dan } \\
\text { sangat sopan }\end{array}$ \\
\hline 11 & $\begin{array}{l}\text { Seragam } \\
\text { pramuniaga }\end{array}$ & $\begin{array}{l}\text { Sangat Tidak } \\
\text { rapih dan sangat } \\
\text { tidak bersih }\end{array}$ & $\begin{array}{l}\text { Tidak rapih } \\
\text { dan tidak } \\
\text { bersih }\end{array}$ & $\begin{array}{l}\text { Kurang rapih } \\
\text { dan kurang } \\
\text { bersih }\end{array}$ & $\begin{array}{l}\text { Cukuprapihdancu } \\
\text { kupbersih }\end{array}$ & Rapih dan bersih & $\begin{array}{l}\text { Sangat rapih dan } \\
\text { sangat bersih }\end{array}$ \\
\hline 12 & $\begin{array}{l}\text { Perhatian } \\
\text { pramuniaga } \\
\text { dalam } \\
\text { melayani } \\
\end{array}$ & $\begin{array}{l}\text { Sangat Acuh } \\
\text { dan tidak } \\
\text { memperhatikan } \\
\text { konsumen }\end{array}$ & $\begin{array}{l}\text { Tidak } \\
\text { memperhati } \\
\text { kan } \\
\text { konsumen }\end{array}$ & $\begin{array}{l}\text { Kurang } \\
\text { memperhatikan } \\
\text { konsumen }\end{array}$ & $\begin{array}{l}\text { Cukuptanggapdal } \\
\text { ammembantukon } \\
\text { sumen }\end{array}$ & $\begin{array}{l}\text { Cepat tanggap } \\
\text { dalam membantu } \\
\text { konsumen }\end{array}$ & $\begin{array}{l}\text { Sangat cepat tanggap } \\
\text { dalam membantu } \\
\text { konsumen }\end{array}$ \\
\hline 13 & $\begin{array}{l}\text { Kecepatan } \\
\text { transaksi }\end{array}$ & Sangat lambat & Lambat & Kurang cepat & Cukup cepat & Cepat & Sangat Cepat \\
\hline 14 & $\begin{array}{l}\text { Tidak ada } \\
\text { alternative } \\
\text { pembayaran }\end{array}$ & $\begin{array}{l}\text { Terdapat satu } \\
\text { item alternative } \\
\text { pembayaran }\end{array}$ & $\begin{array}{l}\text { Terdapat } \\
\text { dua item } \\
\text { alternative } \\
\text { pembayaran }\end{array}$ & $\begin{array}{l}\text { Terdapat tiga } \\
\text { item alternative } \\
\text { pembayaran }\end{array}$ & $\begin{array}{l}\text { Terdapa tempat } \\
\text { item } \\
\text { alternatifpembaya } \\
\text { ran }\end{array}$ & $\begin{array}{l}\text { Terdapat lima } \\
\text { item alternative } \\
\text { pembayaran }\end{array}$ & $\begin{array}{l}\text { Terdapat enam item } \\
\text { alternative pembayaran }\end{array}$ \\
\hline
\end{tabular}

